\title{
Community Empowerment Based on Local Potentials Through the Creation of "Cassava Nugget" Products in Dukuh Binangun, Werdi Village, Paninggaran District
}

\author{
Rizqi Toyibah ${ }^{1}$, Happy Sista Devy ${ }^{2}$, M. Sultan Mubarok ${ }^{3}$, Ade Dedi Rohayana ${ }^{4}$, Ali \\ Muhtarom $^{5}$, Tamamudin ${ }^{6}$, Nia Marotina ${ }^{7}$, Farah Fadillah Syaufii ${ }^{8}$, Hendri Hermawan \\ Adinugraha $^{9 *}$ \\ 1,2,3,4,5,6,7,8,9 Department of Islamic Economy, Faculty of Economics and Islamic Business, IAIN \\ Pekalongan, Indonesia. \\ * Corresponding Author: \\ Email: hendri.hermawan@,iainpekalongan.ac.id
}

\begin{abstract}
.
The problems studied in this study are how the process of potential-based community empowerment through processing of cassava nugget product creations and how the results of community empowerment based on local potential through processing of cassava nugget product creations in Hamlet Binangun, Werdi village, Paninggaran district. The objectives of this study include (1) to determine the process of community empowerment based on local potential through the processing of cassava nugget product creations in Binangun hamlet, Werdi village, Paninggaran sub-district (2) to find out the results of community empowerment activities based on local potential through the processing of cassava nugget product creations in Binangun village hamlet. Werdi, Paninggaran sub-district. This service method uses a descriptive qualitative approach. The results of research from community empowerment activities based on local potential through the processing of cassava nugget product creations are fostering an entrepreneurial spirit, utilizing existing natural potential, increasing skills by creating products that have selling value, and increasing family income or income.
\end{abstract}

Keywords: Community empowerment, local potential, and cassava nuggets.

\section{INTRODUCTION}

Hamlet Binangun, Werdi Village has quite extensive agricultural land. This is evidenced by the number of farmers as the main livelihood. Most of the Werdi Hamlet is surrounded by rice fields and plantations. With such natural conditions, local residents make use of the existing land for their livelihoods. Residents whose livelihoods are farmers try to take advantage of the fertile natural potential, namely by cultivating crops such as vegetables, tubers and others. One type of tuber that is often found in this village is cassava [1][2].

With this natural potential, it becomes a profitable opportunity for the local community if it is utilized properly [3]. One of the obstacles in the effort to exploit this potential is the lack of community sensitivity to the natural potential that is owned and the lack of community skills to manage this potential. In addition, some people in the 
Binangun hamlet of Werdi village prefer to migrate so that the existing natural potential is neglected.

In fact, if the community is sensitive and equipped with the skills to manage this potential [4], it can be an effort to increase family income and reduce the number of unemployed considering the high unemployment rate in the village.

Table. 1. Unemployment data of Werdi village

\begin{tabular}{|l|c|}
\hline \multicolumn{2}{|c|}{ Unemployment } \\
\hline Number of labor force (population aged 18 - 56 years) & 1744 people \\
\hline $\begin{array}{l}\text { The total population aged 18 - 56 who are still in school and not } \\
\text { studying }\end{array}$ & 387 people \\
\hline Total population aged 18 - 56 years who become housewives & 658 people \\
\hline Total population aged 18 - 56 years who work full time & 165 people \\
\hline The number of working population aged 18 - 56 years is not fixed & 533 people \\
\hline $\begin{array}{l}\text { The number of people aged 18 - 56 years who are disabled and do } \\
\text { not work }\end{array}$ & 0 people \\
\hline The number of disabled and working residents aged 18 - 56 years & 1 people \\
\hline
\end{tabular}

Table. 2. Family real income of Werdi village

\begin{tabular}{|l|cc|}
\hline \multicolumn{2}{|c|}{ Family Real Income } \\
\hline Number of Family Heads & 757 & $\begin{array}{c}\text { Family } \\
\text { Heads }\end{array}$ \\
\hline Number of Family Members & 3326 & People \\
\hline Total Income of Head of Family & IDR 750.000 \\
\hline Total income of working family members & IDR 500.000 \\
\hline Total Family Income & IDR 1.250 .000 \\
\hline Average income of family members & IDR 284.501 \\
\hline
\end{tabular}

Given the low per capita income of the family in this village, a solution is needed to boost the economic level of the community. One of the efforts that can be done is through community empowerment. Empowerment is creating a local community that has the initiative or idea and the ability to carry out the initiative on its own [5]. In addition, the goal to be achieved from community empowerment is to form independent individuals and communities [6]. This independence includes independence to think, act and control what they do. Community independence is a condition experienced by society characterized by the ability to think, decide and do something that is deemed appropriate [7]. 
The empowerment process contains two tendencies. First, the empowerment process which emphasizes the process of giving or transferring some power, power or ability to the community so that individuals become more empowered. The first tendency can be called the primary tendency of the meaning of empowerment. While the second tendency or secondary tendency emphasizes the process of stimulating, encouraging or motivating individuals to have the ability or empowerment to determine what their life choices are through the process of dialogue [8].

Community economic empowerment is an effort to empower a community [9], which is carried out by making the community aware of the situation or conditions around it and the empowerment effort is carried out in a village or a village where many people live in unfavorable conditions and want to change their life to become a community [10]. be better and become an independent and empowered society in the economic sector [11]. Community empowerment can be done by providing skills to the community to manage their natural potential [12]. With these skills, it will be able to absorb labor from the local community and can increase community income, as well as reduce unemployment and improve community welfare [13]. In a difficult economic situation like today with a decreasing level of employment opportunity and a tendency to increase in poverty and unemployment, it is necessary to take concrete action to overcome these problems. One of them is the community empowerment program [14]. This program is carried out to create a more prosperous, advanced, and independent society. Community empowerment efforts can be carried out through various sectors, one of which is the utilization of natural resource potentials. Empowerment is carried out by providing skills to local communities through the utilization of existing natural potentials [15]. One of the efforts to exploit natural potential, such as the abundance of cassava in the area, is to create products made from cassava. The product creation is the processed cassava nugget which of course has a selling value and competitiveness because the product is different from other cassava products in general.

Research on community empowerment based on local potential through the creation of "cassava nuggets" in Dukuh Binangun, Werdi Village, Paninggaran District. The problems studied in this study are how the process of potential-based community empowerment through processing of cassava nugget product creations and how the results of community empowerment based on local potential through processing of cassava nugget product creations in Hamlet Binangun, Werdi village, Paninggaran district. Therefore, the purpose of this study was to determine the process of community empowerment based on local potential through the processing of cassava nugget product creations in the Binangun hamlet, Werdi village, Paninggaran district and to find out the results of community empowerment activities based on local potential through the processing of cassava nugget product creations in Binangun hamlet, Werdi village, sub-district of Paninggaran. 


\section{METHODS}

This study used descriptive qualitative method [16]. The object of this research is all residents of Dukuh Binangun, Werdi Village, Paninggaran District. Primary data taken from participant observation, direct interviews with the merchant community between schools and secondary data from documentation as supporting data. So that the data collection techniques used in collecting data in this study were: the main technique used in-depth interviews, as a support used observation and document analysis.After the required data has been collected, it is necessary to process it with data analysis. The data analysis technique used in processing the data of this research is ethnographic, namely from the field note, then coding, categorization or classification is then arranged systematically and then the themes are arranged based on the results of the data analysis. As a starting material as well as an analysis knife, if necessary, relevant theories and the results of previous research that support this research are used. The validity of the data to avoid the errors of the analyzed data, the validity of the data needs to be tested in several ways as follows: Collecting data continuously on the same research subjects; Triangulation on other sources that can be accounted for; and checking by research subjects.

\section{RESULT AND DISCUSSION}

\section{Description of the Situation of the Werdi Village Community}

1. Geographical Conditions

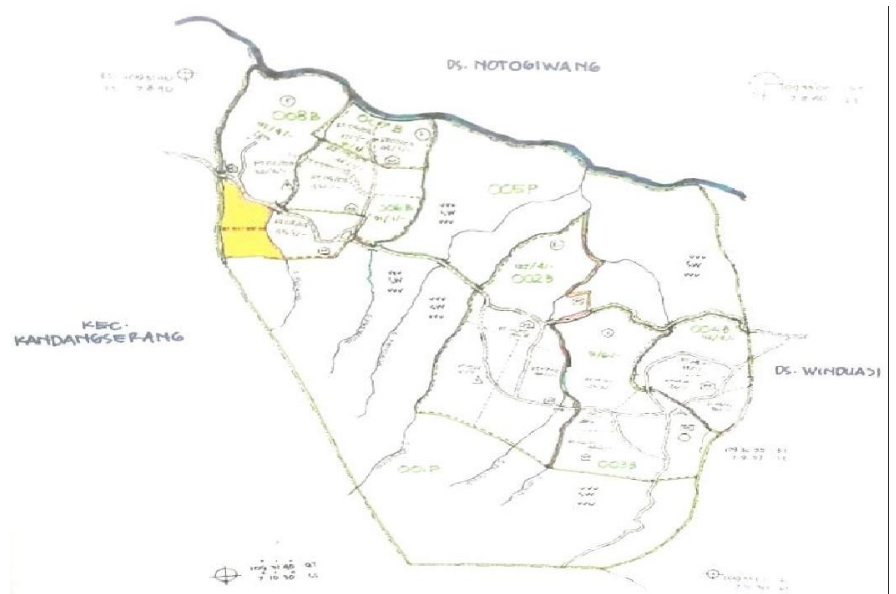

Fig. 1. Werdi Village Map

Werdi Village is one of the villages in the Paninggaran District, Pekalongan Regency. Geographically, Werdi Village, Paninggaran District is approximately $30 \mathrm{~km}$ from the capital city of Kajen, Pekalongan Regency. The area is relatively remote, namely the border with Bubak Village, Kandangserang District.

Werdi Village has an area of 200 ha, has 72 ha of dry land and 25 ha of residential area. As for the boundaries of the area adjacent to Werdi Village, namely: 
Table. 3. Boundaries of Werdi Village

\begin{tabular}{|c|c|c|}
\hline Limit & Village / Sub-district & Districts \\
\hline North side & Winduaji & Paninggaran \\
\hline South side & Sukoharjo & Kandangserang \\
\hline East side & Winduaji & Paninggaran \\
\hline West side & Bubak & Kandangserang \\
\hline
\end{tabular}

Werdi Village is located in a hilly fortress area with an area of $200 \mathrm{ha} / \mathrm{m} 2$, and has a type of soil with a gray clay textured and has a slope of 600 land. Werdi Village has an altitude above sea level of about 600 meters, this makes Werdi Village. It has a tropical climate with two seasons, namely the rainy season and summer, and has $5 \mathrm{~mm}$ of rainfall with 7 months of rainy months and an average daily temperature of 350C.

Werdi Village is a typical village that has natural resources that are very supportive for agricultural activities and other activities such as plantations or food processing with raw materials sourced from nature.

Werdi Village consists of 4 hamlets or hamlets, 4 RW and 15 RT. Among others:

a. Dukuh Werdi

b. Dukuh Binangun

c. Dukuh Sawit

d. Dukuh Karangnangka

\section{Demographics}

The population development in Werdi Village, Paninggaran District, Pekalongan Regency in 2017 is as follows:

Table. 4. Population development in Werdi Village

\begin{tabular}{|c|c|c|}
\hline \multirow{2}{*}{$\begin{array}{c}\text { Total } \\
\text { population }\end{array}$} & \multicolumn{2}{|c|}{ Gender } \\
\cline { 2 - 3 } & Male & Female \\
\hline 2021 & 1676 people & $\begin{array}{c}1684 \\
\text { people }\end{array}$ \\
\hline 2020 & 1669 people & $\begin{array}{c}1675 \\
\text { people }\end{array}$ \\
\hline
\end{tabular}

\begin{tabular}{|c|c|c|c|}
\hline Number of Families & $\begin{array}{c}\text { Male Family } \\
\text { Heads }\end{array}$ & $\begin{array}{c}\text { Female } \\
\text { Family Heads }\end{array}$ & Total \\
\hline $\begin{array}{c}\text { Number of Family Heads this } \\
\text { year }\end{array}$ & $738 \mathrm{FH}$ & $9 \mathrm{FH}$ & $747 \mathrm{FH}$ \\
\hline
\end{tabular}




\begin{tabular}{|l|l|l|l|}
\hline Number of Family Heads last year & $746 \mathrm{FH}$ & $11 \mathrm{FH}$ & $757 \mathrm{FH}$ \\
\hline
\end{tabular}

\section{Economic Conditions}

Table. 5. Economic conditions of Werdi Village

a. Livelihoods of residents

\begin{tabular}{|c|c|}
\hline Agricultural Sector & Amount \\
\hline Farmer & 1206 People \\
\hline Farm workers & 187 People \\
\hline Agricultural business owner & 17 People \\
\hline
\end{tabular}

\begin{tabular}{|l|c|}
\hline \multicolumn{1}{|c|}{ Small Industry \& Home Crafts Sector } & Amount \\
\hline Mechanic & 1 People \\
\hline Bricklayer & 53 People \\
\hline Carpenter & 62 People \\
\hline Tailor & 8 People \\
\hline Cake baker & 4 People \\
\hline Weaver & 6 People \\
\hline
\end{tabular}

\begin{tabular}{|c|c|}
\hline Medium and Large Industrial Sector & Amount \\
\hline Private company employees & 23 People \\
\hline Government company employees & 3 People \\
\hline
\end{tabular}

\begin{tabular}{|c|c|}
\hline Trade Sekor & Amount \\
\hline Effects of trade in agricultural products & 5 People \\
\hline Agricultural product trade service workers & 8 People \\
\hline
\end{tabular}

\begin{tabular}{|l|l|}
\hline \multicolumn{1}{|c|}{ Service Sector } & Amount \\
\hline $\begin{array}{l}\text { The owner of a transportation and transportation service } \\
\text { business }\end{array}$ & 3 People \\
\hline $\begin{array}{l}\text { Transportation and transportation service business } \\
\text { workers }\end{array}$ & 5 People \\
\hline Government employees & 7 People \\
\hline
\end{tabular}




\begin{tabular}{|l|c|}
\hline Police & 1 People \\
\hline Private Midwife & 1 People \\
\hline Civil Servant Retirement & 5 People \\
\hline Private Pension & 11 People \\
\hline Housemaid & 79 People \\
\hline Driver & 7 People \\
\hline Female Migrant Workers & 107 People \\
\hline Male Migrant Workers & 505 People \\
\hline
\end{tabular}

\begin{tabular}{|l|c|}
\hline \multicolumn{2}{|c|}{ Unemployment } \\
\hline Number of labor force (population aged 18 - 56 years) & 1744 people \\
\hline $\begin{array}{l}\text { The total population aged 18 - 56 who are still in school and not } \\
\text { studying }\end{array}$ & 387 people \\
\hline Total population aged 18 - 56 years who become housewives & 658 people \\
\hline Total population aged 18 - 56 years who work full time & 165 people \\
\hline The number of working population aged 18 - 56 years is not fixed & 533 people \\
\hline $\begin{array}{l}\text { The number of people aged 18 - 56 years who are disabled and do not } \\
\text { work }\end{array}$ & 0 people \\
\hline The number of disabled and working residents aged 18 - 56 years & 1 people \\
\hline
\end{tabular}

b. Income per capita by business sector

\begin{tabular}{|l|c|}
\hline \multicolumn{2}{|c|}{ Agriculture } \\
\hline Number of farmer households & 398 Families \\
\hline The total number of members of the farmer household & 1206 People \\
\hline The number of farm worker households & 54 Families \\
\hline Number of household members of farm laborers & 187 People \\
\hline $\begin{array}{l}\text { Total income per capita from the agricultural sector for } \\
\text { each agricultural household }\end{array}$ & IDR 750.000 \\
\hline
\end{tabular}

\section{Livestock}

Number of farm households 


\begin{tabular}{|l|c|}
\hline The total number of members of the farm household & $167 \quad$ People \\
\hline Number of household farm workers & $32 \quad$ Families \\
\hline Number of household members of farm workers & 109 People \\
\hline $\begin{array}{l}\text { Total income per capita from the livestock sector for each } \\
\text { livestock household }\end{array}$ & IDR 925.000 \\
\hline
\end{tabular}

\begin{tabular}{|l|c|}
\hline \multicolumn{2}{|c|}{ Craft } \\
\hline The number of craftsman households & 267 Families \\
\hline The total number of household members of the craftsman & 789 People \\
\hline The number of handicraft worker households & 6 Families \\
\hline Number of household members of craftsman workers & 29 People \\
\hline $\begin{array}{l}\text { Total income per capita from the craftsman sector for each } \\
\text { craftsman household }\end{array}$ & IDR 200.000 \\
\hline
\end{tabular}

\begin{tabular}{|l|c|}
\hline \multicolumn{2}{|c|}{ Services and Trade } \\
\hline Number of service and trade sector households & 6 Families \\
\hline The total number of members of the trade services household & 26 People \\
\hline Number of household service workers and trade & 7 Families \\
\hline Number of household members of service and trade workers & 32 People \\
\hline $\begin{array}{l}\text { Total income per capita from the service and trade sectors for each } \\
\text { service and trade household }\end{array}$ & IDR 800.000 \\
\hline
\end{tabular}

\begin{tabular}{|l|cc|}
\hline \multicolumn{2}{|c|}{ Family Real Income } \\
\hline Number of Family Heads & 757 & FH \\
\hline Number of Family Members & 3326 & People \\
\hline Total Income of Head of Family & IDR 750.000 \\
\hline Total income of working family members & IDR 500.000 \\
\hline Total Family Income & IDR 1.250.000 \\
\hline Average income of family members & IDR 284.500 \\
\hline
\end{tabular}


c. Prosperity level

\begin{tabular}{|l|l|}
\hline \multicolumn{2}{|c|}{ Family Welfare } \\
\hline Number of underprivileged families & 370 Families \\
\hline Number of prosperous families 1 & 184 Families \\
\hline Number of prosperous families 2 & 106 Families \\
\hline Number of prosperous families 3 & 63 Families \\
\hline Number of prosperous families 3 plus & 34 Families \\
\hline Total number of household heads & $757 \quad$ Families \\
\hline
\end{tabular}

\section{The hopes of the people of Dukuh Binangun, Werdi Village}

In an effort to increase the economic welfare of the community through empowerment by utilizing local potential, it cannot be obtained instantly. Various efforts must be made, especially from the awareness and enthusiasm of the local community to achieve these goals. From these community activities or efforts, social and economic impacts will emerge that can improve the lives of the people.

The hope of Mr. Lukman as the Head of Werdi Village, he expects:

1. Werdi villagers, especially young people and women who have more knowledge, creativity and innovation, so they don't go overseas so that existing local potentials can be utilized.

2. The community is able to explore and develop the potential that exists in the village of Werdi, especially in the Binangun hamlet.

3. The community masters the skills provided and is able to open new business opportunities.

4. The acquired skills can be used in a sustainable manner.

5. Received attention from the government in providing training to the community.

6. The community becomes more independent and increases community income through the skills they have.

Meanwhile, other hopes of the Werdi community are that this community empowerment have a positive impact on the social and economic life of the community. Can improve people's lives, reduce poverty and unemployment, and can provide new knowledge for young people about the natural environment.

\section{CONCLUSION}

This community empowerment program is carried out to create a more prosperous, advanced, and independent society. Community empowerment efforts can be carried out through various sectors, one of which is the utilization of natural 
resource potentials. Empowerment is carried out by providing skills to local communities through the utilization of existing natural potentials. With these skills, it will be able to absorb labor from the local community and can increase community income, as well as reduce unemployment and improve community welfare. In addition, existing natural resources are optimally managed.

The recommendation for the village government is to form a UMKM group, the empowerment program should be sustainable so that it will achieve significant development. Recommendations for the community are that the community is expected to be able to actively participate in various programs for treating shellfish waste as long as it does not conflict with the prevailing ethics and norms. The community should control the existence and appropriateness of the program to be implemented.

\section{ACKNOWLEDGMENTS}

The authors are grateful to the LP2M IAIN Pekalongan for supporting this project, to the the people of Werdi Village for the use of the research object. We also thank Faculty of Economics and Islamic Business leaders for the invaluable advices.

\section{REFERENCES}

[1] D. S. V. M.Kes, D. A. R. S.E.,MM., and D. S. MSi, "Potentials, Constraints and ShariaBased Financing Models on Cassava Agroindustry BUMDes in Jember District Indonesia," Int. J. Soc. Sci. Humanit. Invent., vol. 5, no. 2, 2018, doi: 10.18535/ijsshi/v5i2.09.

[2] K. Murniati, S. Widjaya, A. Rabiatul, and I. Listiana, "Climate change adaptation strategy for sustainability and food security of cassava farming households in Lampung, Indonesia," J. Agric. Ext., vol. 23, no. 2, 2019, doi: 10.4314/jae.v23i2.14.

[3] H. H. Adinugraha, Sih Darmi Astuti, and M. Sartika, "Desa Karya" Sebuah Kajian Untuk Mengurangi Tingkat Pengangguran Di Pedesaan (Studi Pada Komunitas Pandai Besi Di Desa Kajar, Gunung Kidul, Yogyakarta)," J. Sains Manaj., vol. 2, no. 2, pp. 69-83, 2016.

[4] N. Mantovani, M. Pizzolati, and S. Gillard, "Engaging communities to improve mental health in African and African Caribbean groups: a qualitative study evaluating the role of community well-being champions," Heal. Soc. Care Community, vol. 25, no. 1, 2017, doi: $10.1111 / \mathrm{hsc} .12288$.

[5] Y. J. Jung, "A study on measures to promote rural community empowerment project for residents in jinja, uganda: Focused on on-site investigation on the feasibility of creating a tourism agriculture complex," J. People, Plants, Environ., vol. 23, no. 1, 2020, doi: 10.11628/ksppe.2020.23.1.1.

[6] L. Magalhaes and A. D. Hartanto, "Model Pemberdayaan Berbasis Pemanfaatan Sumberdaya Alam Berkelanjutan: Studi Pada Program Energi Terbarukan Di Kabupaten Jombang," J. Din. Ekon. Pembang., vol. 3, no. 1, 2020, doi: 10.33005/jdep.v3i1.104.

[7] I. Amaliah, T. Aspiranti, and W. Riani, "The Measurement of Community Independence and Participation in the Establishment of Microfinance Institutions," 
Mimb. J. Sos. dan Pembang., vol. 34, no. 2, 2018, doi: 10.29313/mimbar.v34i2.3823.

[8] L. H. Rifqi, "Community Empowerment through Islamic Microfinances: Perceptions in Comparison," Shirkah J. Econ. Bus., vol. 2, no. 1, 2018, doi: 10.22515/shirkah.v2i1.35.

[9] B. Surya, S. Syafri, H. Sahban, and H. H. Sakti, "Natural resource conservation based on community economic empowerment: Perspectives on watershed management and slum settlements in Makassar City, South Sulawesi, Indonesia," Land, vol. 9, no. 4, 2020, doi: 10.3390/land9040104.

[10] Hukmiah, "Community economic empowerment the bajo tribe is based on local potential (A case study in Bajoe village, east tanete riattang sub-district bone)," Int. J. Sci. Technol. Res., vol. 9, no. 4, 2020.

[11] T. Priyanto and M. A. Fathoni, "Potential Mapping of Pesantren as Community Economic Empowerment Capital,” J. Econ. Business, Gov. Challenges, vol. 2, no. 1, 2019, doi: 10.33005/ebgc.v2i1.65.

[12] I. Hakim, "Muhammadiyah's Framework on The Community Economic Empowerment," FALAH J. Ekon. Syariah, vol. 3, no. 2, 2018, doi: 10.22219/jes.v3i2.7680.

[13] R. D. R. Utama, Z. Fitrandasari, M. Arifin, and R. Muhtadi, "Can Mosque Fund Management For Community Economic Empowerment? : An Exploratory Study," Int. J. Islam. Bus. Ethics, vol. 3, no. 2, 2018, doi: 10.30659/ijibe.3.2.451-457.

[14] K. Xue, D. Xu, and S. Liu, "Social network influences on non-agricultural employment quality for part-time peasants: A case study of Sichuan Province, China," Sustain., vol. 11, no. 15, 2019, doi: 10.3390/su11154134.

[15] R. C. Mukti, A. Arsi, and A. D. Pangawikan, "PKM Pemanfaatan Buah Nipah Di Desa Teluk Betung, Kecamatan Pulau Rimau, Kabupaten Banyuasin, Sumatera Selatan," Qardhul Hasan Media Pengabdi. Kpd. Masy., vol. 6, no. 1, 2020, doi: 10.30997/qh.v6i1.1966.

[16] Sugiyono, Metode Penelitian Kombinasi (mixed Methods), vol. 6, no. 1. 2018. 